\title{
Analysis of the Influence of Yu'e Bao on China's Credit Market from the Perspective of Currency Multiplier
}

\author{
Yujing Li \\ Natural Science, Michigan State University, 48825, USA
}

Keywords: Currency multiplier, Balance treasure, Commercial bank, Currency electronic

\begin{abstract}
With the development of the Internet, Tencent and Alibaba Group launched e-moneys represented by WeChat Pay and Alipay respectively. The booming of electronic money has had an impact on real money and commercial bank payments. This paper takes the currency multiplier effect as the analysis framework and discusses the impact of Yu'e Bao on commercial banks. At the same time, the theoretical analysis using the currency multiplier formula has a certain significance for the study of the development of electronic currency.
\end{abstract}

\section{The concept of money multiplier based on internet financial background}

The so-called currency multiplier, also known as the monetary expansion coefficient or the monetary expansion multiplier, refers to the credit expansion factor generated by the role of the commercial bank's creation of deposit money on the basis of the base currency, which is the multiple of the money supply expansion. The money multiplier reflects the dependence of the total supply of money on the amount of money in the society and the amount of money in the base currency. It can also be used to illustrate the ability of financial intermediaries to create money. In the process of money supply, there is an objectively multiplied (or contracted) effect or reaction between the initial money supply of the central bank and the final formation of social money, which is called the multiplier effect.

Zhou Guangyou's research shows that electronic money has the effect of amplifying the money multiplier, and it exacerbates the volatility of the money multiplier, which reduces the stability of the money multiplier, and the endogenousness of the money multiplier is significantly enlarged, thus controlling the central bank's total money supply. The amount of challenges presented. Xie Haifang and Zhang Dandan proposed that the high income of Yu'ebao and the convenience of the barrier-free exchange of funds with Alipay caused the reduction of cash held by residents and the relocation of savings deposits. By affecting the cash leakage rate and the deposit structure of commercial banks, the money multiplier becomes larger, which leads to the expansion of credit scale and challenges the central bank's financial supervision. Yang Yifan mentioned the issue of electronic money, and can directly play the role of the currency creation mechanism to influence the currency multiplier.

\section{The development of electronic money represented by Yu'ebao}

\subsection{Analysis of the operation mechanism of Yubao}

Yu'ebao is a sales system linked to the Tianhong Fund developed on the Alipay website. The essential attribute of Yu'ebao is actually a money fund. Similar to other money fund-type wealth management products, the main capital investment is a low-risk money market. It set up a third-party payment platform to stimulate netizens to conduct goods transactions through the network. This leads to the fact that in the process of buying and selling goods, the amount of objective idle funds deposited by third-party platform accounts has spawned the birth of Yu'ebao.

Yu'ebao breaks the rules and creates more and more users and more and more demands with its low threshold, wide user and simple operation. As a third-party payment settlement tool, Yu'ebao provides a large amount of customer resources for this money fund. In particular, the seamless link 
between Alipay and Yu'ebao enables users to get a perfect experience. If there is free money in Alipay, they will invest in the balance treasure. When they want to use the money, they can transfer funds from Yuzhongbao, and they will arrive in real time without any formalities. Fee. Most importantly, the originally idle funds can earn more than ten times the current bank deposits by purchasing money funds.

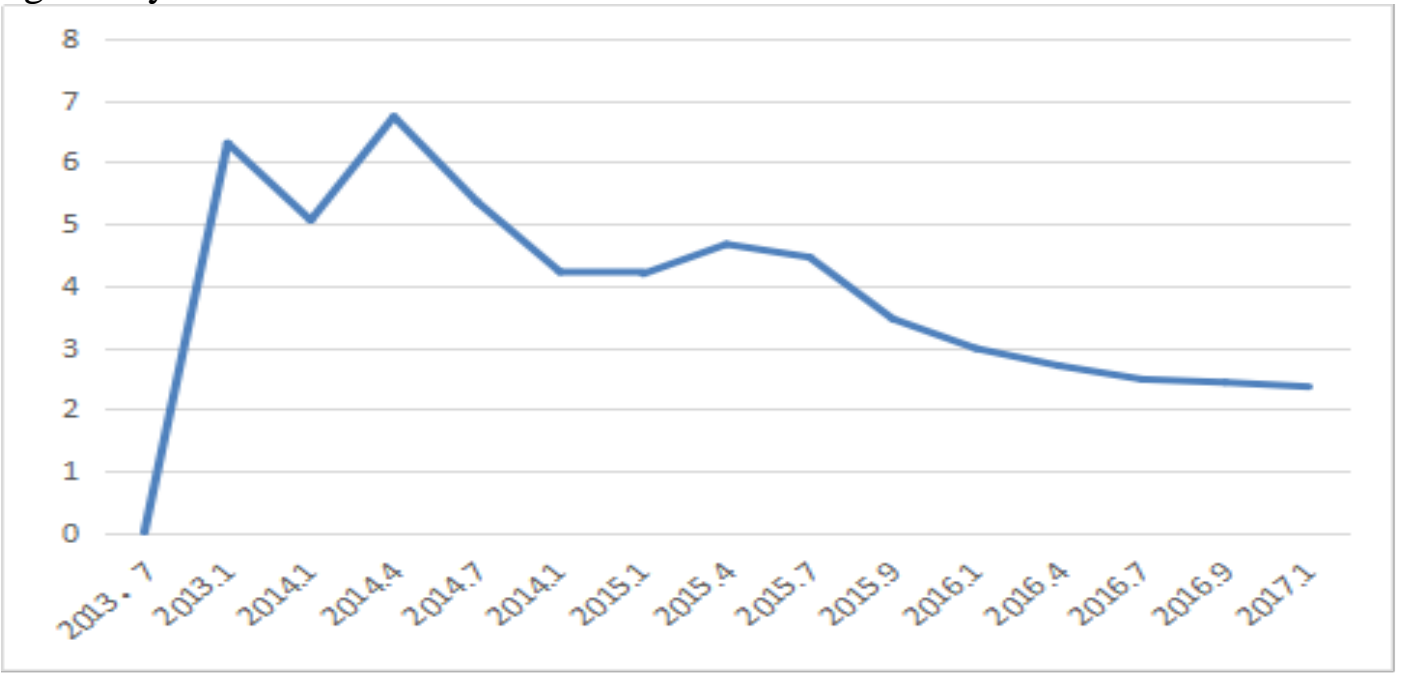

Fig 1 2013-2017 balance treasure income change chart

\subsection{The advantage of Yu'ebao}

\subsubsection{Higher income}

Yu'ebao has two advantages in terms of revenue, with emphasis on liquidity and risk: From the perspective of liquidity, Yu'ebao can complete the redemption of funds within 2 hours, and its strong liquidity can be considered equivalent to demand deposits. Secondly, in terms of risk, Yu'ebao is a money fund, mainly based on a very low-risk currency market. From the actual operation process, the money fund has not experienced such a crisis. In summary, regardless of liquidity or risk, Yu'ebao can be said to be almost the same as demand deposits, and the yield is far ahead.

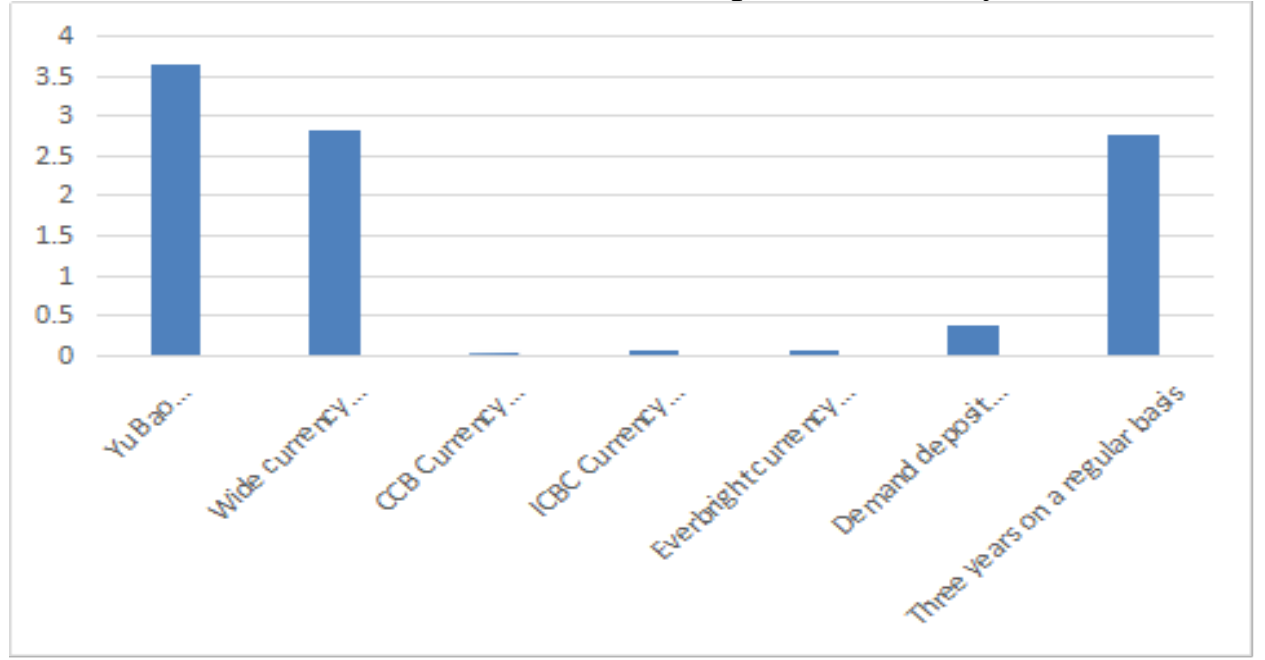

Fig 22017 bank deposits and money fund income comparison

\subsubsection{The investment procedure is simple, the cost is low, and the threshold is low}

Relatively speaking, for the money fund, the investment threshold is relatively high, and the minimum limit for the purchase is 1,000 yuan, which cannot be compared with the balance. Second, from the perspective of fees, Yu'ebao has higher returns and has an absolute advantage.

\subsubsection{Good user experience}

Customers have a lot of traditional business procedures in commercial banks. They need to go 
through a series of formalities. In addition, commercial banks have diverse and complex businesses. It is also a challenge to independently apply online banking to complete business. . In contrast, Yu'e Bao, with its big data advantage, has a user experience advantage that is far ahead of other competitors. In addition, the funds invested in Yu'ebao have strong liquidity. In addition to being able to be used for payment at any time, it is also possible to quickly complete the transfer and withdrawal, and the redemption of the fund is very simple and rapid.

\subsubsection{Big Data Advantage}

Yu'e Bao uses the vast amount of data he has searched to refine the research on user activities and business characteristics. The Aarma model built has improved the previous timing model. Using this model, it is possible to estimate the direction and magnitude of future capital changes, and help Yu'ebao to make a more rational asset portfolio and optimize the use of funds.

\subsubsection{The stability of funds is strong}

The users of Yu'ebao are characterized by scattered and small investment amount. It is precisely because these two points disperse and block the risks, so that Yu'ebao is not affected by the instability of the capital market and is turbulent. Different from the ordinary money fund, the balance treasure is closely related to the consumption scene in essence, which allows users to enjoy the functions of consumer shopping and capital preservation and value-added at the same time, and enhance the balance and customer loyalty. Therefore, Yu'ebao has strong stability.

\section{The impact of Yu'ebao on commercial banks}

\subsection{Impact on commercial bank liability business}

Commercial banks use monetary funds as their main business target, and the situation of monetary funds directly affects its scale and risk bearing power. The impact of the money fund represented by Yu'ebao on commercial banks is that the personal and unit deposits of commercial banks are transferred to the money fund. First of all, the development of Yu'ebao is inspired by other companies in the market. Baidu and Sina have launched similar products. Traditional commercial banks have also countered the balance treasure by researching and developing money fund management products. Secondly, with the promotion of Yu'ebao and its similar products, the public's concept of financial management has also changed, prompting funds deposited in banks to quickly flock to money market funds. At the same time, Yu'e has made many innovations and improvements to traditional money funds by virtue of network technology, which makes investors' application for redemption faster, lowers investment threshold, calculates income every day, improves liquidity, and docks Alipay and Yu'ebao.

\subsection{Impact on the intermediary business of commercial banks}

The payment settlement function has exerted great influence on the normal economic life, gradually breaking the monopoly payment settlement of commercial banks, and also impacting the intermediary functions of commercial banks in this field. The alternative effect of Yu'ebao on payment settlement to commercial banks can be divided into two categories, namely online substitution and offline substitution. Online substitution mainly refers to the fact that Yu'ebao has weakened the payment intermediary function of online banking. Secondly, in the context of increasingly fierce competition, Internet finance such as Yu'ebao is becoming more and more popular, and customers can easily manage their money through the Internet, which leads to a reduction in the bank's wealth management business.

\subsection{Impact on wealth management business}

At the time of the launch of Yu'ebao, it is the $\mathrm{T}+1$ instant redemption form. It combines financial management and consumption into one. The average annualized rate of return is far ahead of the one-day ultra-short wealth management products of most banks. The general wealth management products in traditional commercial banks are usually in the form of $\mathrm{T}+2$. Although commercial 
banks have launched a number of balance-type wealth management products, the investment threshold and the time of redemption are relatively high compared to the Internet fund products such as Yu'ebao. To be harsh. This has caused customers who have invested in the bank's one-day wealth management products to extend the olive branch to the Internet fund, ultimately affecting the market and profits of the bank's ultra-short-term wealth management products.

\subsection{Impact on the risk exposure of commercial banks}

Internet finance accelerates the diversification of financial instruments, narrowing the spreads, attracting both parties to the transaction and reducing costs and efficiency. In the context of interest rate liberalization, commercial banks are worried about the gradual reduction of income. In order to increase profits, they have to increase their risk appetite and turn to research on innovative businesses or turn to higher-risk businesses, thus causing banks to "low-revenue". A low risk "transformation to a business model of "higher returns and higher risks". The first is technical risk. Mainly due to the popularity and application of the Internet, the number of transactions in banks has increased rapidly according to the order of magnitude, and banks have to increase the requirements for IT operation and maintenance. The second is information security risks. The network has increased the scope and depth of information dissemination. In the process of information circulation, customers' personal, account and transaction information are at risk of being stolen. The internal information of commercial banks is not $100 \%$ safe. The third is public relations risk. With the integration of social networks into thousands of households, the scope and depth of information circulation has developed rapidly. If commercial banks have negative conditions such as operations and reputation, or negative news about risks, they will quickly have a strong negative impact, jeopardizing their own operations. It will also bring turmoil to the entire economic order.

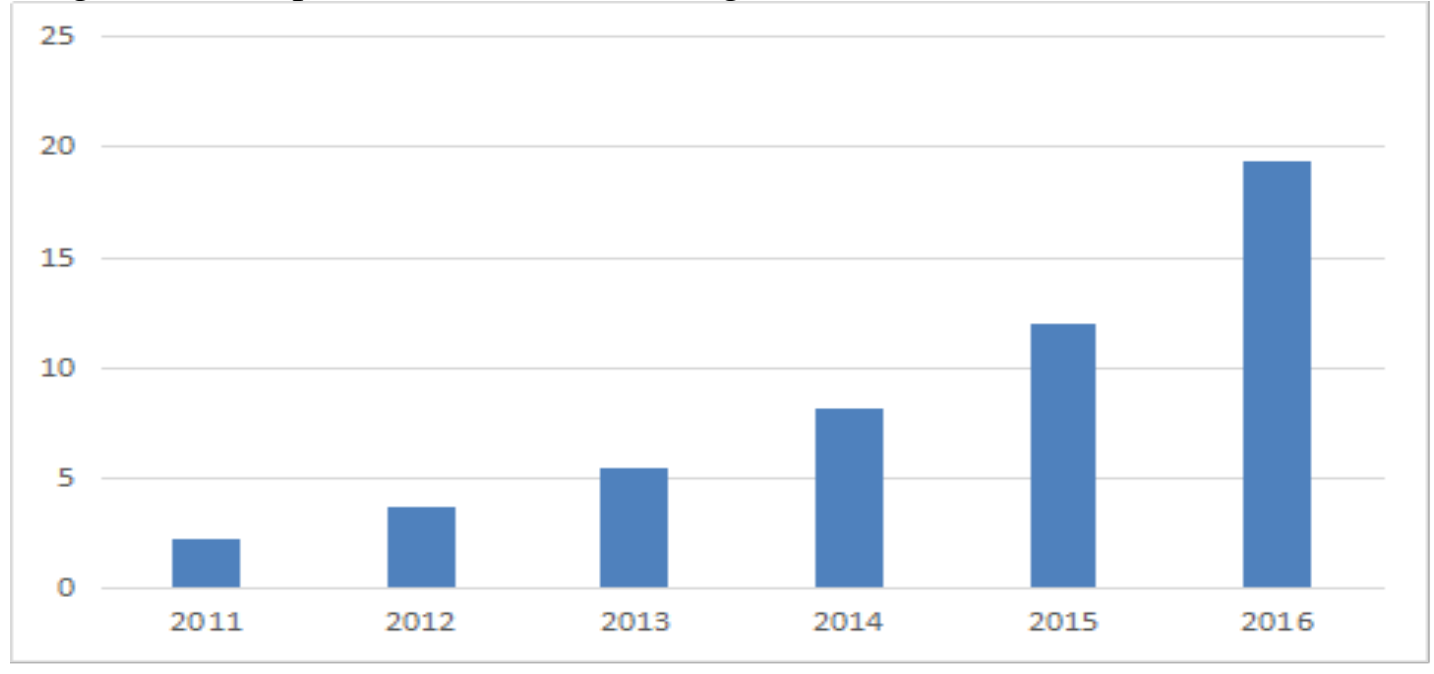

Fig 3 2011-2016 China's third-party Internet payment transaction trend

\section{Alipay impact based on currency multiplier effect}

The currency multiplier is mainly determined by the currency-to-deposit ratio and the reserve-deposit ratio. If the base currency is represented by $\mathrm{B}$, the base currency $\mathrm{B}$ is expressed as cash $\mathrm{C}$ in circulation, statutory deposit reserve $\mathrm{R}$, and excess reserve $\mathrm{E}$. In addition, according to the practice in China, this paper defines the money supply as M2, that is, the money supply includes cash C in circulation, corporate demand deposit D1, resident current savings deposit D2, corporate demand deposit D1, corporate demand deposit D2, enterprise Time deposit T1, enterprise time deposit T2. Record the total time deposit $\mathrm{T}=\mathrm{T} 1+\mathrm{T} 2$, and the total demand deposit $\mathrm{D}=\mathrm{D} 1+\mathrm{D} 2$. Then the currency multiplier formula can be expressed as:

$$
K=\frac{M_{2}}{B}=\frac{C+D+T}{R+C+E}=\frac{C+D+t^{*} D}{R+C+E}=\frac{R_{e}+1+t}{\bar{R}+R_{e}+R_{e}} .
$$


Where $\mathrm{K}$ represents the currency multiplier; $\mathrm{t}$ represents the ratio of time deposits to demand deposits; $\mathrm{RC}$ represents the cash leakage rate; $\mathrm{R}$ represents the average statutory reserve ratio, equal to $R_{d}+t^{*} R$, where $R d$ represents the current reserve requirement rate, and Rt represents Time deposit reserve ratio; Re stands for excess reserve ratio. Regarding the impact of Yu'ebao on the currency multiplier, this paper mainly discusses it from two aspects: its source of funds and the use of funds.

\subsection{Yubao affects the currency multiplier by affecting cash leakage in currency circulation}

Cash leakage refers to the fact that in the process of creating a deposit money in a commercial bank, because the customer withdraws more or less cash from the commercial bank, a part of the cash flows out of the banking system, which is represented by the cash held by the resident or the enterprise and the funds in transit. The more cash held by a company or resident, or the greater the cash leakage in the process of currency circulation, the weaker the ability of money to create credit, and vice versa. Yu'ebao can influence the cash leakage rate in the currency circulation and affect the money multiplier and money supply by affecting the residents' cash holdings. Yu'ebao reduces the cash leakage rate in the circulation system by influencing the trading motives and speculative motives of residents holding money. Assuming other factors are constant, according to the currency multiplier formula: $K=\frac{R_{c}+1+t}{R+R_{c}+R_{e}}$, the decrease in the cash leakage rate will lead to an increase in the money multiplier $\mathrm{R}+\mathrm{R}+\mathrm{R}$. The mechanism of action is as follows:

Assuming that $\mathrm{R}, \mathrm{Re}$, and $\mathrm{t}$ are unchanged, Rc becomes smaller. In this case, the first-order partial derivative of $\mathrm{K}$ to $\mathrm{Rc}$ is obtained: $\frac{\left(R+R_{c}+R_{e}\right)-\left(R_{c}+1+t\right)}{\left(R+R_{c}+R_{e}\right)}=\frac{R+R_{e}-1-t}{\left(R+R_{e}+R_{c}\right)^{2}}$.

Due to the existence of cash leakage rate and other factors affecting currency creation, $(\mathrm{R}+\mathrm{Re}\}<1$, so $(\mathrm{R}+\mathrm{Rc}-1-\mathrm{t})<0$. it can be seen that the money multiplier $\mathrm{K}$ and cash leakage The rate Re is inversely related. It can be seen that $\frac{\partial K}{\partial K_{e}}<0$,that is,the money multiplier $\mathrm{K}$ has an inverse relationship with the cash leakage rate Re.

In other words, Yu'ebao will lead to a decrease in cash leakage rate, while a decrease in cash leakage rate will lead to an increase in the currency multiplier.

\subsection{Yu'ebao influences the currency multiplier by affecting the regular one-time deposit ratio of commercial banks}

Yu'ebao's capital operation model will increase time deposits in the commercial banking system and reduce its current savings deposits. Under other conditions, this change will lead to an increase in the regular one-time deposit ratio of the commercial banking system. The increase in the regular one-time deposit ratio reduces the statutory deposit reserve paid by commercial banks, resulting in an increase in the currency multiplier.Assuming other factors are constant, according to the currency multiplier formula: $K=\frac{R_{c}+1+t}{R+R_{c}+R_{e}}$.

The mechanism of the effect of a regular demand deposit on the currency multiplier is as follows: Assume that Rc, R, and Rc remain unchanged, and when t becomes large, find the partial deviation of $\mathrm{K}$ to $\mathrm{t}: \frac{\partial K}{\partial t}=\frac{\left(R_{d}+t^{*} R+R_{c}+\mathrm{Re}\right)-\left(R_{c}+1+t\right) * R_{t}}{\left(R_{d}+t^{*} R_{t}+R_{c}+\mathrm{Re}\right)^{2}}=\frac{\left(R_{d}-R_{t}\right)-R_{c}\left(1-R_{t}\right)+R_{e}}{\left(R_{d}+t^{*} R_{t}+R_{c}+R_{e}\right)^{2}}$.Since the size of the statutory reserve is between 0 and 1 , and because the central bank's current deposit reserve is greater than the time deposit reserve ratio, (Rd-Rt) $>0$, (1-Rt) $>0$, so $\frac{\partial K}{\partial t}>0$, that is, the currency multiplier $\mathrm{K}$ changes positively with the regular-current deposit ratio. That is to say, under other conditions, the balance will cause the ratio of time deposits to demand deposits to increase, and the increase in the regular one-time deposit ratio will lead to a corresponding increase in the money 
multiplier.

The above analysis shows that Yu'ebao will reduce the cash leakage rate in the currency circulation and increase the periodic one-time deposit ratio of the banking system, thereby expanding the currency multiplier. The result is an increase in the deposit derivation capacity of commercial banks and the currency in the circulation system. The supply has increased. Under the circumstances that the basic money supply, monetary policy and other factors remain unchanged, the increase in the money supply caused by Yu'ebao's capital operation mode will have a greater impact on many areas of China's economic system. This article only analyzes its impact on China's credit market.

The above analysis shows that Yu'ebao will reduce the cash leakage rate in the currency circulation and increase the periodic one-time deposit ratio of the banking system, thereby expanding the currency multiplier. The result is an increase in the deposit derivation capacity of commercial banks and an increase in the money supply in the circulation system. Under the circumstances that the basic money supply, monetary policy and other factors remain unchanged, the increase in the money supply caused by Yu'ebao's capital operation mode will have a greater impact on many areas of China's economic system. The impact of the credit market is analyzed.

\section{References}

[1] Wang Y, Lv H. Study on the influence factors of E-commerce application on the business model of Chinese real estate enterprises[J]. International Journal of U- \& E-Service, Science \& Technology, 2013, 6.

[2] Dan X, Fan Y. Analysis of China's Financial Credit Development Impact on Economic Growth[C]// 2009 international institute of applied statistics studies. 2009.

[3] Zhao H, Ji J, Management S O, et al. A Study on Yield of Yu'E Bao's Influence on the Yield of Financial Products in China's Commercial Banks[J]. Journal of Hebei University of Economics \& Business, 2017.

[4] Chunjuan Zhai, Huang Y. Exploring consumers' use behavior on internet finance in China: From the perspective of the financial products similar to Yu'e Bao[C]// International Conference on Service Systems and Service Management. IEEE, 2016:1-6.

[5] Zhao, H., Ji, J., Management, S. O., Xian Jiaotong University, \& University, S. J. (2017). A study on yield of yu'e bao's influence on the yield of financial products in china's commercial banks. Journal of Hebei University of Economics \& Business. 